\title{
THE TEACHING OF ACUPUNCTURE IN THE UNIVERSITY OF SÃO PAULO SCHOOL OF MEDICINE, BRAZIL
}

João Eduardo Daud Amadera ${ }^{1 *}$, Hong Jin Pal ${ }^{2}$, Wu Tu Hsing ${ }^{3}$, Marcus Zulian Teixeira ${ }^{4}$, Mílton de Arruda Martins ${ }^{5}$, Chin An Lin ${ }^{6}$

Study conducted at the Faculdade de Medicina da Universidade de São Paulo (FMUSP), São Paulo, SP

\author{
*Correspondence: \\ Hospital das Clínicas da \\ FMUSP \\ Serviço de Clínica Médica \\ Geral. Instituto Central. \\ Prédio dos Ambulatórios \\ Av. Dr. Enéas de Carvalho \\ Aguiar, 255, $4^{\circ}$ andar, \\ bloco 6 \\ São Paulo-SP \\ CEP: 05403-000
}

\begin{abstract}
SUMMARY
OвJECtive. Since being introduced as an elective discipline (non-obligatory) in the second semester of 2002, acupuncture has been taught in the University of São Paulo School of Medicine. We conducted this study to verify interest and acceptance among under graduate medical students and to discern a positive influence contributing to improveing their skills.

Methods. The study was conducted from 2002 to 2007 using descriptive statistical methods.

Results. The average number of students who concluded the discipline is 24.9 students per semester with an average number of medical students per semester of 87.5 (28\% of all medical students in the $7^{\text {th }}$ and $8^{\text {th }}$ semesters). After a semester of basic training in acupuncture, only eight students per group are promoted (after selection) to the Medical Academic League of Acupuncture which lasts for two years. Every semester, all eight vacancies are filled. Among the students who concluded the course, $98 \%$ described course quality as good or very good, $85 \%$ considered themselves at least partially able to use acupuncture and $79 \%$ stated that the course influenced them in their medical education. ConcLusion. There is a genuine interest to learn acupuncture, almost $30 \%$ of all students volunteer for a brief training in acupuncture while some of them choose additional training of two years indue to the importance of acupuncture as part of professional skills. Results indicate that acupuncture should be included as an elective discipline for medical students.
\end{abstract}

KEY wORDS: Acupuncture. Complementary therapies. Education, medical. Curriculum. Attitude.

\section{INTRODUCTION}

Acupuncture is one of the healing techniques of Traditional Chinese Medicine, whose wide collection of healing techniques also includes herbal medicine, treatment with diet, massage (tui-na), moxabustion, and exercises such as tai-chi-chuan. Traditional Chinese Medicine (TCM) has been practiced for ages in China, Japan, Korea and other countries in Asia and more recently has found many adepts worldwide. As one of the most popular healing modalities in TCM, acupuncture was first introduced in Brazil in the first decades of the $20^{\text {th }}$ Century and quickly attracted attention of physicians, most of them educated in orthodox medicine. After years of teaching and practicing effort, medical acupuncture was recognized as a medical specialty in Brazil, in 1995.

Although having reached the status of a medical specialty, until recently, acupuncture/TCM was not taught in any medical school in Brazil and there were no training stages in medical residence. In 2002, in order to better inform medical students about other modalities of unorthodox diagnosis and therapy systems, two elective disciplines, homeopathy and acupuncture, were introduced for under graduate medical students at the University of São Paulo School of Medicine, in their 7 th semester $(1,2)$.

The elective discipline of acupuncture offers a total of 40 positions each semester and has created an Academic League of Acupuncture to provide further practical training for students who, having concluded the discipline, decide to continue their learning in acupuncture. After an admissions examination, 8 positions per semester are offered.

We carried out this study to determine if the elective discipline of acupuncture could help under graduate medical students to acquire new skills and knowledge in an unorthodox medical system.

1. Médico fisiatra do Hospital das Clínicas da Faculdade de Medicina da Universidade de São Paulo, São Paulo, SP

2. Médico especialista em acupuntura e médico colaborador do Instituto de Ortopedia e Traumatologia, Centro de Acupuntura do Hospital das Clínicas da Faculdade de Medicina da Universidade de São Paulo - HCFMUSP, São Paulo, SP

3. Professor doutor da Disciplina de Telemedicina, Departamento de Patologia da Faculdade de Medicina da Universidade de São Paulo - FMUSP, São Paulo, SP

4. Coordenador da Disciplina Fundamentos da Homeopatia da Faculdade de Medicina da Universidade de São Paulo - FMUSP, São Paulo, SP

5. Professor Titular da Disciplina de Clínica Médica Geral, Departamento de Clínica Médica da Faculdade de Medicina da Universidade de São Paulo - FMUSP, São Paulo, SP

6. Professor Colaborador, Departamento de Clínica Médica da Faculdade de Medicina da Universidade de São Paulo - FMUSP, São Paulo, SP 
The teaching of acupuncture in the University of São Paulo School of Medicine, Brazil

\section{Methods}

From the second semester of 2002 to the first semester of 2007, all students who chose Acupuncture as an elective discipline were invited to answer a questionnaire pertaining to the a) quality of the acupuncture course; b) ability to indicate acupuncture as treatment; c) indication of acupuncture as therapeutic option, even not being an acupuncturist; d) consideration of principles of Traditional Chinese Medicine as a basis of clinical thinking to reach a diagnosis; e) ability to use acupuncture; f) usefulness of the acupuncture course to help in the choice of a future specialty in medicine; g) contribution of acupuncture to the individual's medical education. As this was not a quantitative study, questionnaires answered were submitted only to descriptive analysis. The study did not involve experimental or medical procedures that could interfere directly in the voluntary participants' health conditions, nor was professional secrecy disclosed, thus, all the participants were assured that they would not be identified. An informal consent was obtained orally from participants.

\section{RESULTS}

The study was carried out, a posteriori, for of a total of 249 students who concluded the elective discipline of Acupuncture from second semester 2002 to first semester 2007. Only 183 students were contacted and invited, of which 85 accepted participation in the project (46\%). It was difficult to contact the students and obtain consent to answer the questionnaire because the majority had already concluded the medical course and did not wish to participate in the study. Even among thouse who participated in the study, not everyone answered all the questions. The average number of students per semester who concluded the discipline is 24.9 , and the average number of medical students per semester is 87.5 . A total of $28 \%$ of all medical students in the $7^{\text {th }}$ and $8^{\text {th }}$ semester participated in the discipline of Acupuncture (Table 1).

Eighty-six students considered the course excellent, 46 (54\%) stated it was very good, while 37 (44\%) considered it good. Two ( $2 \%$ ) found it regular and none considered it bad. $85(100 \%)$ of those who concluded the course considered themselves qualified (64\%) and partially qualified (36\%) to indicate acupuncture as treatment. 81 (99\%) of students, after the course, even not being a specialist, would indicate acupuncture as treatment option. 34 (40\%) of students do not use Traditional Chinese Medicine (TCM) concepts in their clinical judgment, while 10 (12\%) were indifferent. $41(48 \%)$ said they use TCM concepts. 72 (85\%) students considered themselves qualified, (35\% totally qualified and $50 \%$ partially qualified), to use acupuncture. 58 ( $88 \%$ ) students chose their future specialty without decisive influence of the acupuncture course (35\% were indifferent and $33 \%$ did not undergo any influence at all), only $27(32 \%)$ said that acupuncture had influenced their choice. For 79 (93\%) students, acupuncture enhanced their medical education, only $5(6 \%)$ were indifferent, and one thought acupuncture did not affect his or her medical education.

\begin{tabular}{|c|c|}
\hline Semester/year & $\begin{array}{l}\text { Number of students who participated in the discipline } \\
\text { (\% compared to the total of students/semester) }\end{array}$ \\
\hline Second/2002 & $2(2.2 \%)$ \\
\hline First/2003 & 12 (13.7\%) \\
\hline Second/2003 & 27 (30.8\%) \\
\hline First/2004 & $26(29.7 \%)$ \\
\hline Second/2004 & $21(24 \%)$ \\
\hline First/2005 & $35(40 \%)$ \\
\hline Second/2005 & $27(30.8 \%)$ \\
\hline First/2006 & $28(32 \%)$ \\
\hline Second/2006 & $42(48 \%)$ \\
\hline First/2007 & $29(33.1 \%)$ \\
\hline
\end{tabular}

In 2004, as a complement of the discipline, The Medical Academic League of Acupuncture was founded. Since then, after the semester of basic training in acupuncture, only 8 students per group were promoted (after selection) to the Medical Academic League of Acupuncture, which has a duration of two years. Table 2 shows the number of students per semester admitted to the League.

Table 2 - Total of students registered in the Discipline, interested in the League, total of positions offered and total of admitted

\begin{tabular}{|c|c|c|c|c|c|}
\hline & $\begin{array}{l}2^{\text {nd }} \text { Semester } \\
2004\end{array}$ & $\begin{array}{c}\text { 1rst Semester } \\
2005\end{array}$ & $\begin{array}{l}\text { 2nd Semester } \\
\quad 2005\end{array}$ & $\begin{array}{l}\text { 1rst Semester } \\
2006\end{array}$ & $\begin{array}{c}\text { 2nd Semester } \\
2006\end{array}$ \\
\hline Students registered in the Discipline & 21 & 35 & 27 & 28 & 42 \\
\hline Students interested in League & 10 & 12 & 14 & 13 & 12 \\
\hline Positions offered by the League & 5 & 5 & 5 & 7 & 7 \\
\hline Total of admissions (official + extra admissions) & 8 & 8 & 7 & 9 & 9 \\
\hline
\end{tabular}




\section{Discussion}

In view of the medical students' growing interest in Complementary and Alternative Medicine (CAM) learning ${ }^{(3)}$, over the last years medical schools of countless countries have started to include, the teaching of these therapeutic modalities in the basic undergraduate curriculum.

A survey carried in 2002 among 484 students of the University of São Paulo School of Medicine(4) showed that over $85 \%$ of respondents believed that homeopathy and acupuncture should be included in the undergraduate curriculum (elective: $72 \%$; compulsory: $19 \%$ ), with 56\% very interested in learning. Around $35 \%$ of the students were in favor of offering such specialties in public health clinics, while an average of 34\% advocated the provision of these treatments also in hospitals, whereas $60 \%$ believed they could be integrated with conventional medical practice.

Similarly, results obtained in other surveys ${ }^{(5-11)}$ indicated that the majority of medical students is interested in learning the fundamentals of homeopathy and acupuncture and are favorable to include ting these disciplines in the undergraduate curriculum. Although a significant number of interviewees ignored the main reasons for use of these unconventional therapies, as well as their effectiveness, most of them defended the use of these medical specializations in public health care, for integration with conventional medicine, seeking to increase the physicianpatient relationship and to enlarge the spectrum of action of the medical art.

Surveys of 1996 in the United Kingdom ${ }^{(12)}$ showed that 23\% of the medical schools had incorporated in their curriculum some disciplines that supplied basic concepts on the several forms of CAM. In 1999, 40\% of the European Union's medical schools offered CAM Disciplines ${ }^{(13)}$. In the period between 1997-1998, research in 117 American medical schools ${ }^{(14)}$ showed that $64 \%$ of them included CAM disciplines with an increase of this estimate in the latter surveys ${ }^{(15)}$. Research done in Canadian medical schools in 1998 pointed out that $81 \%$ of them presented CAM topics in their curriculum ${ }^{(16)}$. A survey in 80 Japanese medical schools $^{(17)}$, over the period $1998-1999$, showed that $20 \%$ of them taught CAM, a total of 25 disciplines, mostly teaching of acupuncture.

Multiple methods were used to drive CAM integration in the curriculum. Several schools seized the opportunity of concurrent curriculum reform or course revisions to integrate CAM. Although integration was the optimal goal, stand-alone or elective courses facilitated curriculum innovation by circumvent some institutional issues testing new material or teaching strategies and uncovering faculty talents and content interests. Electives were an effective format to assess and build interest before making a course required. Successful elective materials subsequently were incorporated into required courses (University of Massachusetts, Louisiana State University and others), because of popularity with students and recognition of importance by the faculty members. Several schools built on existing, successful CAM-related centers or programs (University of California-San Francisco, University of North Carolina, University of Michigan, and University of Minnesota). ${ }^{(18-20)}$

Although the total of students enrolled in the study may not have been convincingly representative ( $46 \%$ of the total of students that concluded the discipline - Table 1), and this would be a loss for this study, considering the universe of students that concluded the elective discipline of acupuncture, there is some interesting information we can obtain from the study.

Almost the totality of students (98\%) considered the Elective Discipline of Acupuncture as, at least, a good discipline (54\% considered excellent, $44 \%$ considered good). It is very unusual to have this level of approval, since it is not an obligatory discipline. Independent of the fact that the profile of candidates who choose the discipline of acupuncture might have a tendency to qualify the discipline as very good, the quality of the discipline is that this tendency cannot be contaminated. A growing number of students in this discipline (Table 1), as well as the increasing number of candidates interested in continuing training in acupuncture at the Academic League of Acupuncture (Table 2) support the idea of the good quality of the discipline, de per se, attracts students.

Among the students who concluded the discipline, 64\% considered themselves able to indicate acupuncture as option of treatment, while 36\% considered themselves partially able to indicate acupuncture. Once more, this data shows the good quality of the discipline, in spite of the qualification resulting from a self-evaluation questionnaire.

Almost the totality of the students that concluded the discipline would indicate acupuncture as a therapeutic option, which demonstrates the confidence of the students after the conclusion of the discipline. Only $48 \%$ of the students use concepts of Traditional Chinese Medicine in their clinical judgment however $52 \%$ do not, data that suggests that probably it is easier to learn acupuncture than the concepts of Traditional Chinese Medicine. Indirectly, it could lead to the idea that, under some circumstances, perhaps in the initial stage, acupuncture may be taught without a profound link to Traditional Chinese Medicine.

Almost all of students ( $35 \%$ able and $50 \%$ partially able) considered themselves capable of using acupuncture, which once more reflects the quality of the discipline. Considering the influence that the discipline could have had in the choice of the future medical specialties, acupuncture did not show decisive influence upon student choice (32\% answered affirmatively, $33 \%$ answered negatively and 35\% were indifferent), but students confirmed that the discipline had definitively helped in the their medical education (93\%), possibly increasing knowledge of non conventional healing techniques, similar to other elective courses in various modalities of $\mathrm{CAM}^{(21-23)}$.

Although the Elective Discipline of Acupuncture has been offered to students only since 2002 , it has contributed decisively to the education of under - graduate students, not only offering a good quality of discipline, but also promoting an opportunity of learning a healing technique not belonging to the main stream medical system, challenging students to consider other healing systems as an option to main stream medical treatment. From the evaluation of the questionnaire, we can conclude that the Elective Discipline of Acupuncture is important to the education of under - graduate students in the University of São Paulo School of Medicine.

Conflict of interest: none 
The teaching of acupuncture in the University of São Paulo School of Medicine, Brazil

\section{Resumo}

\section{O ensino da acupuntura na Faculdade de Medicina da Univer- Sidade de São Paulo, Brasil}

OBJetivo. Após ter sido introduzida como disciplina eletiva (não obrigatória) no segundo semestre de 2002, a acupuntura tem sido ensinada na Faculdade de Medicina da Universidade de São Paulo (FMUSP) desde então. Esse estudo foi realizado com o intuito de verificar o interesse e a aceitação da acupuntura entre os estudantes de medicina da FMUSP e se, de alguma forma, ela poderia influenciá-los positivamente, contribuindo para melhorar as suas competências.

Métodos. O estudo foi conduzido durante o período de 2002 a 2007, utilizando-se métodos de estatística descritiva.

Resultados. A média de todos os estudantes que concluíram a disciplina foi de 24,9 alunos por semestre, sendo que a média de estudantes de medicina por semestre é de 87,5 (28\% de todos os estudantes de medicina nos $7^{\circ}$ e $8^{\circ}$ semestres). Após o primeiro semestre de formação básica em acupuntura, apenas oito alunos por grupo são promovidos (após seleção) para a Liga Médica Acadêmica de Acupuntura, que tem a duração de dois anos. Em todos os semestres, as oito vagas são preenchidas. Entre os estudantes que concluíram o curso, 98\% consideraram-no de boa ou muito boa qualidade, $85 \%$ consideravam-se parcialmente capazes para empregar a acupuntura e $79 \%$ consideraram que o curso contribuiu para a sua educação médica.

Conclusão. Existe um real interesse para a aprendizagem da acupuntura, pois em torno de $30 \%$ de todos os alunos quiseram passar por um breve treinamento em acupuntura, alguns deles optando por uma formação de dois anos em reconhecimento à importância da acupuntura como parte da capacitação profissional. Os resultados sugerem que a acupuntura deve ser incluída como uma disciplina eletiva para alunos de medicina. [Rev Assoc Med Bras 2010; 56(4):458-61]

Unitermos: Acupuntura. Terapias complementares. Educação médica. Currículo. Atitude.

\section{REFERENCES}

1. Universidade de São Paulo. USP Júpiter - Sistema de Graduação. Faculdade de Medicina. Clínica Médica. Disciplina: MCM 0773 - Fundamentos da Homeopatia. Disponível em: http://sistemas2.usp.br/jupiterweb/ obterDisciplina?sgldis = MCM0773

2. Universidade de São Paulo. USP Júpiter - Sistema de Graduação. Faculdade de Medicina. Clínica Médica. Disciplina: MSP 0668 - Introdução à Acupuntura: Disponível em: http://sistemas2.usp.br/jupiterweb/ obterDisciplina?sgldis $=$ MSP0668

3. Teixeira MZ, Lin CA, Martins MA. O ensino de práticas não-convencionais em saúde nas faculdades de medicina: panorama mundial e perspectivas brasileiras [The teaching of non-conventional practices regarding health care in medical schools: world scenario and Brazilian perspectives]. Rev Bras Educ Med. 2004;28:51-60
4. Teixeira MZ, Lin CA, Martins MA. Homeopathy and acupuncture teaching at Faculdade de Medicina da Universidade de São Paulo: the undergraduates' attitudes. São Paulo Med J. 2005;123:77-82.

5. Marcus DM. How should alternative medicine be taught to medical students and physicians? Acad Med. 2001;76:224-9.

6. Sampson W. The need for educational reform in teaching about alternative therapies. Acad Med. 2001;76:248-50.

7. Murdoch-Eaton D, Crombie H. Complementary and alternative medicine in the undergraduate curriculum. Med Teach. 2002; 24:100-2.

8. Maizes V, Schneider C, Bell I, Weil A. Integrative medical education: development and implementation of the comprehensive curriculum at the University of Arizona. Acad Med. 2002;77:851-60.

9. Yeo AS, Yeo JC, Yeo C, Lee CH, Lim LF, Lee TL. Perceptions of complementary and alternative medicine amongst medical students in Singapore - a survey. Acupunct Med. 2005; 23:19-26.

10. Chaterji R, Tractenberg RE, Amri H, Lumpkin M, Amorosi SB, Haramati A A large-sample survey of first- and second-year medical student attitudes towardcomplementary and alternative medicine in the curriculum and in practice. Altern Ther Health Med. 2007;13:30-5.

11. Münstedt K, Harren H, Von Georgi R, Hackethal A. Complementary and alternative medicine: comparison of current knowledge, attitudes and interest among German medical students and doctors. Evid Based Complement Alternat Med. 2008. [Epub ahead of print].

12. Morgan D, Glanville H, Mars S, Nathanson V. Education and training in complementary and alternative medicine: to postal survey of UK universities, medical schools and faculties of nurse education. Comp Ther Med. 1998;6:64-70.

13. Barberis L, Toni AND, Schiavone M, Zicca THE, Ghio R. Unconventional medicine teaching at the Universities of the European Union. J Alternat Complement Med. 2001;7:337-43.

14. Wetzel MS, Eisenberg DM, Kaptchuck TJ. Courses involving complementary and alternative medicine at U.S. medical schools. JAMA. 1998;280:784-87.

15. Brokaw JJ, Tunnicliff G, Raess BU, Saxon DW. The teaching of complementary and alternative medicine in U.S. medical schools: the survey of course directors. Acad Med. 2002;77:876-81.

16. Ruedy J, Kaufman DM, MacLeod H. Alternative and complementary medicine in Canadian medical schools:a survey. Can Med Assoc J. 1999;160:816-7.

17. Tsuruoka K, Tsuruoka Y, Kajii E. Complementary medicine education in Japanese medical schools: a survey. Complement Ther Med. 2001;9:28-33.

18. Pearson NJ, Chesney MA. The CAM Education Program of the National Center for Complementary and Alternative Medicine: an overview. Acad Med. 2007;82:921-6.

19. Lee MY, Benn R, Wimsatt L, Cornman J, Hedgecock J, Gerik S, et al. Integrating complementary and alternative medicine instruction into health professions education: organizational and instructional strategies. Acad Med. 2007:82:939-45.

20. Sakowski HA, Markert RJ, Jeffries WB, Coleman RM, Houghton BL, KosokoLasaki S, et al. Dimensions of clinical medicine: an interclerkship program. Teach Learn Med. 2005;17:370-5.

21. Laken MP, Cosovic S. Introducing alternative/complementary healing to allopathic medical students. J Altern Complement Med. 1995;1:93-8.

22. Ben-Arye E, Frenkel M. Between metaphor and certainty: teaching an introductory course in complementary medicine. Harefuah. 2001;140:855-9.

23. Torkelson C, Harris I, Kreitzer MJ. Evaluation of a complementary and alternative medicine rotation in medical school. Altern Ther Health Med. 2006;12:30-4.

Artigo recebido: 03/03/10

Aceito para publicação: 20/05/10 